Published in final edited form as:

Cancer Lett. 2016 September 28; 380(1): 340-348. doi:10.1016/j.canlet.2015.12.022.

\title{
Regulation of Prostate Cancer Progression by the Tumor Microenvironment
}

\author{
Stephen L. Shiao ${ }^{1,{ }^{*}}$, Gina Chia-Yi Chu ${ }^{2,{ }^{*}}$, and Leland W. K. Chung ${ }^{3}$ \\ ${ }^{1}$ Departments of Radiation Oncology and Biomedical Sciences, Cedars-Sinai Medical Center, Los \\ Angeles, CA 90048 \\ 2Departments of Medicine, Cedars-Sinai Medical Center, Los Angeles, CA 90048 \\ ${ }^{3}$ Departments of Medicine and Surgery, Cedars-Sinai Medical Center, Los Angeles, CA, 90048
}

\begin{abstract}
Prostate cancer remains the most frequently diagnosed cancer in men in North America, and despite recent advances in treatment patients with metastatic disease continue to have poor fiveyear survival rates. Recent studies in prostate cancer have revealed the critical role of the tumor microenvironment in the initiation and progression to advanced disease . Experimental data has uncovered a reciprocal relationship between the cells in the microenvironment and malignant tumor cells in which early changes in normal tissue microenvironment can promote tumorigenesis and in turn tumor cells can promote further pro-tumor changes in the microenvironment. In the tumor microenvironment, the presence of persistent immune infiltrates contributes to the recruitment and reprogramming of other non-immune stromal cells including cancer-associated fibroblasts and a unique recently identified population of metastasis-initiating cells (MICs). These MICs, which can also be found as part of the circulating tumor cell (CTC) population in PC patients, promote cancer cell transformation, enhance metastatic potential and confer therapeutic resistance. MICs act can on other cells within the tumor microenvironment in part by secreting exosomes that reprogram adjacent stromal cells to create a more favorable tumor microenvironment to support continued cancer growth and progression. We review here the current data on the intricate relationship between inflammation, reactive stroma, tumor cells and disease progression in prostate cancer.
\end{abstract}

\section{Keywords}

prostate cancer; metastasis; tumor microenvironment; metastasis-initiating cells; circulating tumor cells; exosomes; tumor immunology; microRNA

\footnotetext{
*Address for correspondence: Stephen L. Shiao, MD, PhD, Department of Biomedical Sciences, Cedars-Sinai Medical Center, Gina Chia-Yi Chu, PhD, Department of Medicine, Cedars-Sinai Medical center, stephen.shiao@cshs.org; chia-yi.chu@cshs.org.

Publisher's Disclaimer: This is a PDF file of an unedited manuscript that has been accepted for publication. As a service to our customers we are providing this early version of the manuscript. The manuscript will undergo copyediting, typesetting, and review of the resulting proof before it is published in its final citable form. Please note that during the production process errors may be discovered which could affect the content, and all legal disclaimers that apply to the journal pertain.
} 
In both Europe and the United States, prostate cancer remains the most commonly diagnosed non-cutaneous malignancy in men and the second most common cause of cancer death worldwide.[1,2] Numerous studies of prostate cancer histology have led to the recognition that the tumor microenvironment composed of both immune and non-immune cell types plays a large role in the pathogenesis and progression of prostate cancer.[3, 4] The details of the initiating events in prostate cancer remain elusive, but involve a series of cell intrinsic changes in combination with distinct changes in the microenvironment that parallel the progression to malignancy and the subsequent development of metastatic disease.

The tumor microenvironment consists of an interconnected network of stromal fibroblasts, immune cells, blood vessels, mesenchymal stem cells (MSCs) and fat cells, neural cells and secreted soluble and insoluble factors such as chemokines, cytokines and extracellular matrices (ECMs). As tumors develop, the microenvironment undergoes complex changes as a result of interactions between cancer cells and the aforementioned cells in the tumor microenvironment. Critical steps in the development of cancer are regulated by the reciprocal interactions between tumor cells and its microenvironment. The consequence of such interactions can be profound, driving altered tumor cell survival, proliferation and angiogenesis, resistance to therapy, evasion of immune surveillance and increased metastatic spread. In this review, we discuss the role of the different elements of the prostate tumor microenvironment and how they interact to promote the development, progression and metastatic potential of prostate cancer.

\section{Tumor-stroma microenvironment in prostate cancer}

Reciprocal tumor-stroma interactions have been observed and well-appreciated in many forms of solid cancers including prostate cancer. The changes that occur in the stroma adjacent to tumors, called a desmoplastic response or "reactive stroma," leads to aberrant growth and morphologic transformation of the stromal and connective tissues surrounding a tumor. This desmoplastic response contributes to the transition of stromal fibroblasts to myofibroblasts with a concomitant increase in the accumulation and remodeling of the tissue ECMs. This remodeling process leads to the production and elaboration of previously tissuebound critical soluble factors and insoluble matrices akin to the repair response in injured tissue. Release of these molecules sends a danger signal to the immune system leading to the recruitment of infiltrating inflammatory cells. This inflammatory response normally culminates in the regeneration of injured tissue by promoting local angiogenesis and tissue regeneration. However, in the case of cancer a "vicious cycle" involving cross-talk between tumor cells and their adjacent microenvironment generates a persistent inflammatory responses akin to a "wound that does not heal".[5]

\section{Cancer-Associated Fibroblasts (CAFs)}

In prostate cancer, the reactive stroma consists largely of carcinoma-associated fibroblasts (CAFs), also known as myofibroblasts. Stromal changes occur as an early phenomenon in prostate carcinogenesis. CAFs have been observed in premalignant prostatic intraepithelial neoplasia (PIN) and their numbers increase as tumors progress to higher-grade disease. [6, 7] The origin of CAFs remains unclear, but multiple groups have identified different cells of 
origin including existing stromal fibroblasts, circulating marrow-derived progenitors (MSC), vascular pericytes or other as yet unidentified tissue-resident progenitor cells. [8, 9] Regardless of their origin, CAFs appear to be structurally and functionally distinct from normal tissue fibroblasts.[10, 11] Soluble factors and insoluble ECMs secreted by CAFs[12] and their associated cancer cells $[13,14]$ have been experimentally implicated in promoting the transformation of morphologically "normal" but genotypically "altered" prostate epithelial cells to cancer. CAFs enhance the proliferation and invasiveness of prostate cancer cells [15] and encourage the acquisition of therapeutic resistance and immune evasiveness of prostate tumors. [16] Co-opted from their original repair function, CAFs support tumorigenesis and subsequent tumor growth through several mechanisms including accelerated ECM deposition and turn-over. This increased ECM recycling releases previously tissue-bound molecules and leads to production of new growth, survival and angiogenic factors including growth/differentiation factor 15 (GDF15)[17] and cytokines such as transforming growth factor beta (TGF- $\beta$ ) [18].

In addition to the effects on the ECM, stromal cells in the prostate tumor microenvironment, a large proportion of which are CAFs, interact with cancer cells through a number of other non-ECM mediated pathways including direct contact, secretion of soluble factors and extracellular vesicles (EVs) of varying sizes. [19] EVs released in the tumor microenvironment act as transporters and are loaded with cellular DNA, RNA and protein. Recent data has demonstrated that transfer of small non-coding RNAs called microRNAs (miRNAs) through EVs from the CAFs into the adjacent epithelia results in explosive tumor growth in several preclinical mouse models of prostate cancer.[20, 21] This transfer of miRNAs promotes epithelial to mesenchymal transition (EMT) of cancer cells, a process that drives increased cell migration, invasion, and ultimately metastasis to bone and soft tissues.[20, 21] More specifically, studies of miRNA members miR-409, miR-379 and miR-154*, located within the delta-like 1 homolog-deiodinase, iodothyronine 3 (DLK1DIO3) imprinted region located on human chromosome 14, revealed that these miRNAs had tumor-inductive effects in vitro and in prostate cancer xenograft models. DLK1-DIO3 miRNAs have been shown to be essential for embryogenesis and induced pluripotent stem cell formation, and in the setting of prostate cancer appear to be "hijacked" to promote tumorigenesis and metastasis through enhanced tumor-stroma interactions. Cancer cells are susceptible to activation by surrounding cells and factors in the tumor microenvironment leading tumor cells to undergo EMT in the process turning on embryonic neuroendocrine or "stem cell" programs. This process activates pathways that lead to enhanced growth, survival, metastasis and therapeutic resistance of cancer cells. We demonstrated recently that the DLK1-DIO3 cluster miRNAs derived from EVs of CAFs promote EMT and increased stem cell like properties in adjacent epithelial cells in vitro and in vivo.[22]

Through their effects on the ECM and regulation of tumor cell function via EV, CAFs can support the development and progression of prostate cancer though key questions remain about the factors that regulate the reactive stroma and how it interacts with tumor cells. In particular, emerging evidence examining the relationship between the stroma and tumor cells at different stages of disease has revealed the heterogeneity of CAFs and their effects on tumor progression can vary widely with the presence of CAFs at different stages leading to enhanced, unchanged or even impeded tumor progression. 


\section{CAFs contribution to tumor progression: one size does not fit all}

CAFs have been shown inhibit or stimulate tumor growth depending upon the stage, grade, hormonal and differentiation status of a tumor.[23] Experimental models of many solid tumors, including prostate cancer, have shown that CAFs could contribute either positively or negatively to tumor growth. At the molecular level, the complex interaction between $\mathrm{CAFs}$ and prostate cancer is mediated in part by androgen receptor (AR), a master regulator of prostate cancer growth and differentiation. Like CAFs, in different settings the presence of AR has been shown to either an increase or inhibit prostate cancer growth.[24] Although there is no unified explanation for the diverse actions of AR in prostate growth, genomic and non-genomic programming of CAFs by AR in the tumor microenvironment offers a clue. For example, AR function in prostate myofibroblasts was shown to be intimately regulated by a AR co-regulator, hydrogen peroxide-inducible gene 5 (Hic-5), that exerts genomic and non-genomic programming of AR target genes in CAFs via increased phosphorylation of focal adhesion kinase (FAK). Altered AR target genes in CAFs could affect AR-mediated regulation of the growth, cell adhesion, motility and invasion of prostate cancer cells. In the Hic-5 model, Hic-5 acts in concert with AR and FAK to amplify or inhibit regulation of approximately $50 \%$ of the AR target genes in CAFs and coordinates AR signaling via stromal-tumor cell adhesion and ECM production to regulate prostate cancer cell behavior in the tumor microenvironment. In addition to the effect of CAFs on prostate cancer cells, changes in CAFs also have complex effects on the other cells in the tumor microenvironment, particularly the immune cells.

\section{Interactions between inflammation and the reactive stroma}

As discussed above, experimental and pathologic data have all supported the notion that CAFs can influence the development and progression of cancer. However, CAFs do not exist in isolation and increasing evidence indicates that inflammation likely in part through the influence of the immune system on fibroblast programming can also drive carcinogenesis. Inflammation typically refers to the immune cells involved in the clearance of a foreign antigen, though a multitude of other stromal cells participate in an inflammatory response. In particular, once the initial immune response has subsided other stromal cells including vascular endothelial cells, pericytes and smooth muscle cells as well as stromal fibroblasts are activated to restore tissue homeostasis. These two cancer-promoting processes, inflammation and stromal activation, often co-exist and evolve with the development of a tumor. They regulate each other through a complex web of interactions involving the stromal, inflammatory and tumor cells themselves. As in most ongoing pathology, the different components of the microenvironment form a self-reinforcing network that allows tumor cells to achieve states with increased growth, invasion and resistance to therapeutic perturbation.

Multiple groups have drawn parallels between wound repair and cancer likening cancer to an unresolved, chronic inflammatory response.[25, 26] Using this as a paradigm, we can explore the connection between inflammation development of a reactive stroma and the pathogenesis of prostate cancer. All de novo inflammatory responses begin with recognition of non-self antigens, either foreign antigens such as microorganisms or altered self as in the case of damaged or infected cells.[27] In prostate cancer, as prostate epithelial cells progress 
from PIN to high-grade disease, they accumulate increasing numbers of mutations that can lead to immune recognition.[28] In particular, early recognition by innate immune cells such as dendritic cells and macrophages likely serves as one of the starting points of cancerassociated inflammation. Innate cells, in particular macrophages, are critical for shaping the immune response and for establishing an immunosuppressive pro-tumor microenvironment. [29] Macrophages have a complex role in cancer and depending on their phenotype can either promote or inhibit cancer progression. Simplified into two basic phenotypes, M1 macrophages with their cytotoxic potential are considered an "anti-tumor" phenotype whereas M2 macrophages associated with wound healing and tissue repair are typically regarded as the "pro-tumor" phenotype. (Pollard or Coussens ref?) For example in prostate cancer, several pathologic studies have shown that the presence of tumor-associated macrophages, typically of the M2 phenotype, strongly correlates with poorer outcomes potentially due to their powerful regulatory effects on an immune response.

Under normal inflammatory processes, macrophages interact with fibroblasts to promote wound-repair and, in cases of chronic unresolved infections, granuloma formation. This interaction is mediated by macrophage expression of regulatory factors including FGF, EGF and TGF- $\beta$, which promote the development of reactive stroma.[30] Cancer-associated fibroblasts, in turn, also express high levels of TGF- $\beta$ [18] and GDF15 (also known as macrophage inhibitory factor) [17] which can influence the macrophage functional state to encourage a phenotype that promotes an immune inhibitory environment. The macrophage and fibroblast derived TGF- $\beta$ also shapes the T cell response as TGF- $\beta$ promotes the development of regulatory $\mathrm{T}$ cells which have been found in prostate cancer and correlates with worse survival.[31] The immunosuppressive microenvironment once established reciprocally supports the expansion of the reactive stroma through sustained production of growth factors and chemokines from the existing inflammatory cells that continually attract inflammatory cells. This cycle produces a microenvironment that supports cell growth in the guise of tissue repair and ultimately allows for the formation and progression of cancer. Ongoing studies have identified key players in the immune microenvironment of prostate cancer, which includes a wide diversity of immune cells from both innate and adaptive immunity.

\section{Tumor-immune microenvironment in prostate cancer}

\section{The relationship between inflammation and prostate cancer}

Inflammation has long been linked to the development of prostate cancer and it has been long recognized that chronic inflammation is associated with both benign as well as malignant prostate tissue.[32] Histologic studies have found that $80-90 \%$ of prostate cancer specimens had signs of immune infiltrate and, further, that high-grade disease was associated with increased inflammation.[33] Chronic inflammation with its persistent, ongoing immune response is thought to contribute to development and progression of many cancers including prostate cancer.[34, 35] The etiology of chronic inflammation in the prostate remains unclear, but recent evidence suggests that ongoing genotoxic stress from DNA damage occurring during the process of carcinogenesis and exposure to the microbiota? in the urinary tract may be important contributors.[36] The composition of the 
immune infiltrate varies widely with disease stage and patient age, but cells of both the innate and adaptive immune system have been identified within prostate stroma. The majority of the immune infiltrate consists of $\mathrm{CD} 3+\mathrm{T}$ cells (70-80\%, largely CD4+ T cells), CD20+ B cells (10-15\%) and macrophages (10-15\%)[37], but many other immune cell types have also been identified. Novel agents designed to enhance or inhibit the different innate immune cells are now being tested and in part through these studies we are just beginning to understand the complex role these cells play in prostate cancer progression.

\section{Innate immunity and prostate cancer}

Innate immune cells are cells of the immune system that can respond to foreign antigens, but do not develop antigen-specific recognition receptors such as the T or B cell receptors. They regulate the nature and duration of immune responses as a whole by controlling when and how an inflammatory response is initiated and terminated. Many of the innate immune cells also participate in the repair of immune damaged tissue and the return of an organism to its homeostatic state. The major innate immune cells include macrophages, dendritic cells (DC), natural killer (NK) cells, granulocytes (neutrophils, basophils and eosinophils) and mast cells. As many consider cancer a state of aberrant inflammation, it is not surprising that many of the innate cells have been implicated in the development and progression of cancer (Figure 1). With its links to chronic inflammation, innate immune cells and their numbers, particularly macrophages, dendritic cells, mast cells and NK cells have been correlated with patient outcomes. Furthermore, animal studies have revealed that targeting these cells may improve responses to both traditional cytotoxic therapies as well as newer immunotherapies.

As discussed in the previous section, in prostate cancer, like other tumors, most, but not all studies of pathologic specimens[38], find that higher numbers of tumor-associated macrophages correlate with worse prognosis.[39] Additionally, in these studies the M2 phenotype in the macrophages are associated with higher stage tumors and higher Gleason scores.[40, 41] Interestingly, M2-macrophages are thought to also drive other stromal elements, in particular fibroblasts as described above by enhancing the conversion of quiescent fibroblasts to activated myofibroblasts (aka carcinoma-associated fibroblasts), which synergize to promote prostate carcinogenesis.[42] Targeting macrophages using CSF1-inhibitors to block macrophage migration in murine models of prostate cancer restored sensitivity to androgen blockade[43] and improved the efficacy of radiation therapy. [44] Macrophages may also play an important role in metastatic disease as a recent study of metastatic patients following docetaxel demonstrated increased circulating macrophageassociated cytokines in patients with progressive disease.[45] Thus, for prostate cancer, macrophages appear to largely support the development and progression of disease and strategies aimed at reducing macrophage numbers have shown early efficacy in murine models highlighting the potential for human trials.

Natural Killer (NK) cells, innate lymphocytes that respond rapidly to viral infections and other pathogens by recognizing altered or infected cells, play a large role in immune surveillance for multiple types of cancers including skin, breast and melanoma. They have cytotoxic activity against tumor cells and function to regulate the activity of other immune cells through their secretion of important inflammation-initiating cytokines and chemokines. 
Murine models have demonstrated that alterations in NK numbers or activity leads to increased prostate cancer progression and metastases.[46] This was corroborated in patients where increased numbers of CD56+ NK cells in prostate tumors after androgen deprivation therapy was associated with improved prognosis, whereas a low density of CD56+ NK cells predicted for seminal vesicle invasion.[47] Other groups have also found in metastatic prostate cancer patients that higher NK cell activation and cytotoxicity correlated with longer time to castration resistance and improved overall survival.[48] Thus, current data suggests that, like many other cancers, in prostate cancer NK cells serve an important role in reducing the progression of disease and improving the response to therapy.

Other innate cells that contribute to the regulation of prostate cancer include mast cells and neutrophils. Mast cells, tissue resident inflammatory cells that protect against parasites and bacteria through their early production of immunoregulatory cytokines, have been found in prostate cancer and higher numbers of tumor associated mast cells appear to inhibit tumor progression and predict better prognosis,[49, 50] though their role remains controversial as they also appears to be critical mediators of early prostate cancer development through their production of the pro-angiogenic, pro-tumor molecule matrix metalloproteinase 9 (MMP-9). [51] Neutrophils, key early mediators of the innate immune response, appear to correlate with decreased incidence of prostate cancer and better response to therapy in the metastatic setting.[52, 53] However, neutrophils, like mast cells, can serve as source of MMP-9, which was similarly shown to contribute to disease progression in prostate cancer.

In sum, macrophages [54], neutrophils[55] and mast cells [56, 57] mostly exhibit pro-tumor qualities whereas natural killer (NK) cells[58] appear to have an anti-tumor effect though the precise effect of each cell type can differ depending on the stage and grade of the disease and much work remains to be done to fully elucidate the role of these cells play in cancer progression.

\section{Adaptive immunity and prostate cancer}

The adaptive immune system consists of the $\mathrm{T}$ and $\mathrm{B}$ lymphocytes and serves as the end result of most immune responses, with these lymphocytes producing a powerful response consisting of cytotoxic cells, cytokines and antibodies that in a normal immune response work to clear an organism of a foreign antigen and produce lasting immunity ("immunologic memory"). Evidence of existing immune recognition by the adaptive immune system in prostate cancer has been identified in patients with prostate cancer where studies of their circulating $\mathrm{T}$ cell specificity show existing memory $\mathrm{T}$ cell responses against prostate-specific antigen and prostatic acid phosphatase.[59] Fitting with their diverse phenotypes, $\mathrm{T}$ and $\mathrm{B}$ cells play a complex role in the development and progression of cancer as both promoters of cancers and critical components of the anti-tumor immune response.[25]

In prostate cancer, analysis of the tumor infiltrate revealed that the presence of high numbers of T cells or B cells predicted worse capsular and perineural invasion.[60] More specifically, increased numbers of CD4+ or CD8+ T cells correlated with worse biochemical failure-free survival as well as prostate cancer specific survival.[60-62] A significant number of these infiltrating $\mathrm{T}$ cells appear to be $\mathrm{CD} 4+\mathrm{CD} 25+\mathrm{FoxP} 3+$ regulatory $\mathrm{T}$ cells $[63,64]$ which are also elevated in the circulation of patients with prostate cancer.[65, 66] Not only do these 
elevated numbers of regulatory $\mathrm{T}$ cells predict worse survival, they also predict for worse response to immunotherapies including vaccines and anti-CTLA4 blockade.[59, 67] Thus, for prostate cancer, $\mathrm{T}$ cell infiltrates in general appear to predict for worse survival likely due to the fact that many of the infiltrating cells appear to be $\mathrm{T}$ lymphocytes with regulatory activity.

B cells have been implicated in driving the progression of cancer in murine models and regulating the response to therapy through their influence on macrophages.[68, 69] Prostate cancers are highly enriched in B cells, the presence of which positively correlates with higher grade and higher risk of recurrence[70], though previous histologic studies have suggested that B cells present in lymph nodes may be more important than intratumoral B cells.[71] Mechanistically, murine models of prostate cancer have shown that B cells recruited by the chemokine CXCL13 into prostate cancer tumors promote the progression of castrate-resistant prostate cancer by producing lymphotoxin, which activates an I $\mathrm{kB}$ kinase a (IKKa)-BMI1 module in prostate cancer stem cells.[72] Additionally, recent murine studies revealed that immunosuppressive B cells could mediate chemotherapy resistance through the production of the immunosuppressive cytokine IL-10 and expression of the inhibitory ligand PD-L1.[73] Thus, emerging evidence suggests that B cells appear to contribute to prostate cancer progression and treatment resistance in murine models, but further studies in mice and patients are required to fully elucidate which B cell subsets and phenotypes are contributing to progression.

In sum, multiple lines of evidence have revealed that the stromal and immune components found in prostate cancer contribute to the development and progression of disease. However, many questions still remain about how these otherwise normal cells are co-opted to produce a favorable environment for the development of malignancy (Figure 1). Recent mechanistic studies have begun to shed light on this question, with the identification of specific populations of cancer and immune cells and associated secreted factors in the cancer microenvironment that are capable of shaping a favorable tumor microenvironment that allows cancer cells to overcome anti-tumor immunity and culminates in enhanced tumor growth and metastasis.

\section{Tumor cell regulation of the microenvironment}

\section{Circulating Tumor Cells (CTC) reprogram the local microenvironment to permit prostate cancer metastasis}

Metastasis is a highly inefficient process. With the accelerated growth rate of many tumors, it has been increasingly recognized that millions of tumor cells are constantly shed from the primary tumors into the bloodstream and lymphatics detectable as circulating tumor cells (CTC). Given the high number of CTCs and the frequency of clinically apparent metastatic disease the actual rate of cancer cell colonization at metastatic sites appears to be extremely low. In order for CTCs to become metastatic sites of colonization, they must survive travel through the circulation which includes shear stress and deprivation of ECM-derived survival signals in the vasculature.[74] Further, in order to become metastatic lesions in distant organs, cancer cells undergo an EMT process to acquire accelerated growth, enhanced survival and increased motility. Finally, once cancer cells arrive at sites of metastases they 
have to co-opt the resident stromal cells to generate a permissive microenvironment[5]. EMT and survival of CTCs in the circulation have been reviewed extensively elsewhere[75, 76] and so here we review recent developments in how tumor cells alter the microenvironment to allow for development of metastases.

Studies in xenograft murine models with human prostate cancer cells showed efficient growth, survival and colonization of prostate cancer cells at metastatic sites becomes possible when metastatic sites also contain a cluster of specialized cells known as metastases-initiating cells (MIC). MICs do not appear to be classic tumor-initiating or tumor stem cells because they have the ability to recruit and reprogram non-tumorigenic prostate cancerous and non-cancerous epithelial and stromal cells to participate in cancer metastasis. [77, 78] A portion of circulating CTCs are MICs and they can also be found in primary prostate cancer tissues.[48, 79] Histological analysis revealed that the ratio of MICs to other non-MICs and stromal cells in primary prostate cancer tissues predicts patient survival[48]. Interestingly, when CTCs were ex vivo expanded with MICs and reimplanted in immunodeficient mice, the mice grew more tumors. Further, when co-cultured with naïve CTCs, MICs co-opt those CTCs to express MIC phenotype. MICs can travel as single cells or as clusters, often referred to as circulating tumor microemboli (CTMs), that also contain dormant tumor cells ("bystander cells"). Patients with advanced disease, in particular, have increased numbers of CTMs possibly containing MICs and bystander dormant prostate cancer cells $[74,80,81]$ When examined ex vivo, these CTMs have increased survival, metastatic potential and resistance to therapeutic intervention when compared with isolated CTCs $[74,82]$. Thus, it is hypothesized that CTMs comprised of unique populations of CTCs and MICs may be a major source of early metastatic deposits. Once lodged these CTMs thrive as metastatic lesions and continue to grow through recruitment and reprogramming of resident and circulating cells. Using a murine model of prostate cancer Kim et al. discovered self-seeding tumor metastases in which additional circulating cancer cells were recruited to and colonized pre-existing tumor deposits conferring enhanced tumor growth.[83]

It is increasingly evident that malignant cancer cells are capable of recruiting and transforming normal or non-tumorigenic cells to serve as active "co-conspirators" to promote in tumorigenesis, evade immune surveillance and develop distant metastasis. [5, 25, 83] In order to further explore the mechanism by which malignant cells exert effects on other cells in the tumor microenvironment, our group genetically tagged prostate cancer cell lines that overexpress RANKL to isolate MICs that are capable of recruiting bystander dormant cells to participate in the metastatic process allowing the formation of bone and soft tissue metastases.[78] We found that MICs reprogrammed and transformed the recruited non-tumorigenic bystander epithelial cells in the tumor microenvironment. These transformed cells acquired the tumorigenic and metastatic properties of MICs expressing elevated EMT, stem cell, and neuroendocrine genes through transactivation of cMyc/Max and AP4 via RANK receptor-mediated signaling. The interaction between MICs, CTCs and resident bystander dormant cells create a positive feedback cycle in the primary and at metastatic sites to maintain an aggressive pool of prostate cancer cells with programming that endows this pool of cells with increased migratory, invasive and metastatic capabilities. [84] The effect of MICs is wide ranging with in vitro studies of MICs cultured as 3-D organoids, recruited and reprogrammed multiple cell types with tumorigenic and metastatic 
potential including freshly harvested circulating CTCs, disseminated tumor cells (DTCs) from the blood and bone marrow of prostate cancer patients, as well as nontumorigenic dormant prostate cancer cells (DC-1), established from primary prostate cancer tissues.[79, 85] Interestingly, MICs derived naturally, designated as nMICs, from aggressive tumors, display EMT, stemness and neuroendocrine phenotypes and confer tumorigenic and metastatic potential to the naïve bystander prostate cancer cells [86-88].

Examination of the recruited and reprogrammed prostate cancer cells revealed permanent genetic and cytogenetic changes within those cells[14] leading our group and others to speculate that MIC-reprogrammed bystander cells have global changes as a consequence of MIC-induced epigenetic modifications. In particular, we and others have observed alterations in the methylation status of specific gene promoters that encode transcription factors. Studies using low-dose 5-Azacytidine, which inhibits the DNA methyltransferase, demonstrated that expression of MIC-specific transcription factors in normal prostate epithelial DC-1 cells is regulated by changes in the methylation status of the promoters of critical regulatory transcription factors upstream of critical MIC proteins.[89] Closer examination of the transcription factors affected by MICs identified c-Myc as a key downstream regulator governing the activation of EMT, stemness and a neuroendocrine-like phenotype[79] suggesting that MIC-mediated reprogramming of normal prostate epithelial cells might involve transactivation of c-Myc. Additionally, expression of c-Myc was found to be up-regulated in the reprogrammed DC-1 cells by either experimental or nMIC cells. The hypothesis that MIC-mediated reprogramming depends on c-Myc was further tested by downregulating MYC using JQ1, a small-molecule inhibitor targeting the amino-terminal bromodomains of BRD4[90], an epigenetic factor required for transcription of MYC and its downstream targets.[91, 92] In our reprogramming model, we have shown that downregulating MYC with JQ1 treatments attenuated and abrogated the recruitment and reprogramming of DC-1 cells by nMIC cells.[93]

In order to identify other changes that occur in reprogrammed cells, RNA-sequencing analysis was done in a 3-dimentional (3-D) co-culture model where nMIC reprogrammed DC-1 cells which further revealed, that, in addition to c-Myc, FOXM1, a proto-oncogene [94] was also upregulated. FOXM1 serves as a common central transcriptional regulator and activation of FOXM1 subsequently switches on many cell cycle-related downstream target genes, such as PLK1, CCNB1, BIRC5, AURKB, and CDK1. Interestingly, FOXM1 has been shown to play a role in epigenetic regulation where overexpression of FOXM1 can induce methylome reprogramming. Consistent with this concept, using primary normal keratinocytes, Hwang et al found that overexpressing FOXM1 "brainwashed" normal cells to adopt the methylome profile of cancer cells.[95, 96] Moreover, FOXM1 is also important in stem or progenitor cell expansion, which is believed to be involved in cancer initiation.[97] Therefore, combination treatment with small molecules of JQ1 and Siomycin A[98] that target MYC and FOXM1, respectively, might serve as a promising therapeutic strategy to prevent MIC recruitment and reprogramming of surrounding bystander cells halting cancer progression and metastasis (Figure 2).

In addition to identifying the downstream transcription factors in the reprogramming process, there has been much recent interest in understanding the method by which cancer 
cells communicate with the other cells within the microenvironment. As discussed briefly above, direct cell-to-cell contact and soluble factors have been previously identified, but there is emerging evidence that a significant portion of the communication between cancer cells and the non-malignant cells of the tumor microenvironment is mediated through extracellular vesicles.

\section{Extracellular vesicles-mediated communication between cells: reprogramming at a distance}

Extracellular vesicles (EV), circular membrane-enclosed particles, are secreted by various cell types, including tumor cells, cardiovascular cells, neuronal cells, immune and nonimmune cells in the tumor microenvironment.[99] EVs are heterogeneous ranging in size from $30 \mathrm{~nm}-10 \mu \mathrm{m}$ and have different origins depending on the size. The best characterized EVs are exosomes/microvesicles, which are $30-150 \mathrm{~nm}$ particles derived from endosomal compartments called multivesicular bodies (MVB) and are released after fusion of MVBs with the plasma/cell membrane of viable cells[100] The next larger population of EVs are shed vesicles known as ectosomes, with sizes ranging from $100 \mathrm{~nm}$ to $1 \mu \mathrm{m}$. Ectosomes are formed from the budding of the plasma membrane which make cytoplasmic protrusions that later detach from the cell surface.[101] Finally, there are a recently described novel class of EVs called large oncosomes that are much larger in size than exosomes or ectosomes and range from 1-10 $\mu \mathrm{m}$. These oncosomes are produced by shedding of non-apoptotic plasma membrane blebs[102] and were initially identified in prostate cancer cells that had oncogenic overexpression of MyrAkt1, HB-EGF, and caveolin-1 [103] or genetic silencing of the cytoskeletal regulator DIAPH3.[104, 105] EVs, particularly exosomes, have been demonstrated as a critical intercellular communication system for exchange of intracellular information between cells to influence physiological and pathological state of the recipient cells [106]. We and others have identified multiple signaling pathways affected by exosomes released from tumors that shape the microenvironment and promote the development of malignant cells.

Exosomes carry cargoes containing a variety of cytoplasmic proteins, nucleic acids, and lipids protected by a lipid bilayer, reflecting both the identity and internal condition of the cell of origin, but at the same time possessing some unique mixtures of genetic material. [107] Exosomes can 1) directly stimulate target cells by interaction with surface-expressed ligands [108], 2) transfer membrane receptors between cells[109], and 3) mediate the horizontal transfer of proteins and genetic information, such as mRNA, microRNA (miRNA), pre-miRNAs, and other non-coding RNAs between tumor cells.[107, 110-113] Horizontal transfers of protein and RNA contents by exosomes have been implicated in inducing epigenetic reprogramming in target cells as demonstrated by Ratajczak et al. in which adult hematopoietic stem cells can be reprogrammed by exosomes derived from embryonic stem cells by up-regulating early pluripotent and hematopoietic stem cell markers and activating MAPK and Akt.[111] More recently, Melo et al. found that exosomes derived from breast cancer cells or patient serum contain miRNA processing machinery and proteins from the RNA-induced silencing complex (RISC) including Dicer, TRBP, and AGO2, which process pre-miRNAs into mature miRNAs.[114] These cancer-derived exosomes can reprogram non-tumorigenic epithelial cells to form tumors by efficiently silencing mRNA 
thereby altering the target cell transcriptome in a Dicer-dependent manner.[114] Similar observations have been made in our prostate cancer cell models where we identified elevated RANKL levels in exosomes derived from both experimental and nMICs. Examination of MIC-derived exosomes revealed that these exosomes have the capability to reprogram bystander DC-1 cells in both 2-D and 3-D culture systems by up-regulating MIC-specific genes and increasing the migration and invasion of DC-1 cells. This observation suggests that the reprogramming of dormant prostate DC- 1 cells may be mediated by MIC-derived exosomes (Figure 2).

Exosomes have also been shown to regulate the tumor immune response, and depending on the cell of origin and the molecular composition of the exosomes, they may either stimulate or inhibit the immune response in the tumor microenvironment $[115,116]$. Exosomes can stimulate an immune response by directly presenting MHC class proteins to $\mathrm{T}$ cells, indirectly transferring antigen or peptide-MHC complex to dendritic cells, directly activating natural killer cells and macrophages [115, 117], or stimulating B cell activation and subsequent antibody production.[118] Conversely, exosomes may also suppress anti-tumor immunity by inducing apoptosis of activated T-cells and macrophages and preventing monocyte differentiation into dendritic cells.[119] Exosomes also support the generation of a suppressive tumor microenvironment by promoting increased numbers of immune suppressor cells, including myeloid-derived suppressor cells, regulatory T cells, and CD14 ${ }^{+}$, HLA-DR $^{-/ l o w}$ tumor-associated macrophages.[116, 120] Thus, tumor-derived exosomes support a multitude of pro-tumor activities including oncogenic reprogramming, angiogenesis, and immune evasion. Exosomes exert their pro-tumor activity through direct signaling, but also can promote cancer progression and metastasis due to their unique membrane-bound biology which allows them to transfer genetic information among cells in the tumor microenvironment or over long distances by entering into the circulation. While we are just beginning to understand the biology of exosomes current evidence suggests that they are key mediators by which tumors regulate their microenvironment reciprocally and may serve as critical targets for future therapeutics.

\section{Conclusions}

Prostate cancer has long been associated with changes in the normal prostatic tissues consisting of a combination of inflammatory cells such as macrophages and T cells as well as a non-inflammatory cells composed largely of cancer-associated stromal fibroblasts. These inflammatory and non-inflammatory elements in the microenvironment work in concert to produce a stromal microenvironment that is conducive to prostatic epithelial growth and transformation leading to the development of cancer (Figure 1). While it has been well established that the tumor microenvironment can foster a pro-tumor milieu the precise mechanisms underlying the formation of an environment favorable to tumors and the means by which tumor cells and the stroma communicate remain elusive. Recent evidence from our lab and others have identified a new type of circulating tumor cell known as the metastasis-initiating cell which has the unique and powerful capacity to reprogram other cancer cells and normal tissues to produce a tumor microenvironment that enhances tumor growth and metastasis (Figure 2). Further investigation and understanding of the complex relationships between tumors and their associated immune and non-immune 
microenvironment will provide insight into how tumors co-opt normal processed to further their progression and identify new targets for therapy.

\section{References}

1. Shukla ME, Yu C, Reddy CA, Stephans KL, Klein EA, Abdel-Wahab M, Ciezki J, Tendulkar RD. Evaluation of the current prostate cancer staging system based on cancer-specific mortality in the surveillance epidemiology and end results database. Clin Genitourin Cancer. 2015; 13:17-21. [PubMed: 25571871]

2. Siegel R, Ma J, Zou Z, Jemal A. Cancer statistics 2014, CA: a cancer journal for clinicians. 2014; 64:9-29. [PubMed: 24399786]

3. De Marzo AM, Platz EA, Sutcliffe S, Xu J, Gronberg H, Drake CG, Nakai Y, Isaacs WB, Nelson WG. Inflammation in prostate carcinogenesis. Nat Rev Cancer. 2007; 7:256-269. [PubMed: 17384581]

4. Taverna G, Pedretti E, Di Caro G, Borroni EM, Marchesi F, Grizzi F. Inflammation and prostate cancer: friends or foe? Inflammation research : official journal of the European Histamine Research Society ... [et al.]. 2015; 64:275-286.

5. Hanahan D, Weinberg RA. Hallmarks of cancer: the next generation. Cell. 2011; 144:646-674. [PubMed: 21376230]

6. Ayala G, Tuxhorn JA, Wheeler TM, Frolov A, Scardino PT, Ohori M, Wheeler M, Spitler J, Rowley DR. Reactive stroma as a predictor of biochemical-free recurrence in prostate cancer. Clin Cancer Res. 2003; 9:4792-4801. [PubMed: 14581350]

7. Tuxhorn JA, Ayala GE, Rowley DR. Reactive stroma in prostate cancer progression. J Urol. 2001; 166:2472-2483. [PubMed: 11696814]

8. Zeisberg EM, Potenta S, Xie L, Zeisberg M, Kalluri R. Discovery of endothelial to mesenchymal transition as a source for carcinoma-associated fibroblasts. Cancer Res. 2007; 67:10123-10128. [PubMed: 17974953]

9. Placencio VR, Li X, Sherrill TP, Fritz G, Bhowmick NA. Bone marrow derived mesenchymal stem cells incorporate into the prostate during regrowth. PLoS One. 2010; 5:e12920. [PubMed: 20886110]

10. Dakhova O, Ozen M, Creighton CJ, Li R, Ayala G, Rowley D, Ittmann M. Global gene expression analysis of reactive stroma in prostate cancer. Clin Cancer Res. 2009; 15:3979-3989. [PubMed: 19509179]

11. Sung SY, Hsieh CL, Law A, Zhau HE, Pathak S, Multani AS, Lim S, Coleman IM, Wu LC, Figg WD, Dahut WL, Nelson P, Lee JK, Amin MB, Lyles R, Johnstone PA, Marshall FF, Chung LW. Coevolution of prostate cancer and bone stroma in three-dimensional coculture: implications for cancer growth and metastasis. Cancer Res. 2008; 68:9996-10003. [PubMed: 19047182]

12. Hayward SW, Wang Y, Cao M, Hom YK, Zhang B, Grossfeld GD, Sudilovsky D, Cunha GR. Malignant transformation in a nontumorigenic human prostatic epithelial cell line. Cancer Res. 2001; 61:8135-8142. [PubMed: 11719442]

13. Rhee HW, Zhau HE, Pathak S, Multani AS, Pennanen S, Visakorpi T, Chung LW. Permanent phenotypic and genotypic changes of prostate cancer cells cultured in a three-dimensional rotatingwall vessel. In Vitro Cell Dev Biol Anim. 2001; 37:127-140. [PubMed: 11370803]

14. Pathak S, Nemeth MA, Multani AS, Thalmann GN, von Eschenbach AC, Chung LW. Can cancer cells transform normal host cells into malignant cells? British journal of cancer. 1997; 76:11341138. [PubMed: 9365160]

15. Olumi AF, Grossfeld GD, Hayward SW, Carroll PR, Tlsty TD, Cunha GR. Carcinoma-associated fibroblasts direct tumor progression of initiated human prostatic epithelium. Cancer Res. 1999; 59:5002-5011. [PubMed: 10519415]

16. Harper J, Sainson RC. Regulation of the anti-tumour immune response by cancer-associated fibroblasts. Seminars in cancer biology. 2014; 25:69-77. [PubMed: 24406209]

17. Bruzzese F, Hagglof C, Leone A, Sjoberg E, Roca MS, Kiflemariam S, Sjoblom T, Hammarsten P, Egevad L, Bergh A, Ostman A, Budillon A, Augsten M. Local and systemic protumorigenic 
effects of cancer-associated fibroblast-derived GDF15. Cancer Res. 2014; 74:3408-3417. [PubMed: 24780757]

18. Bhowmick NA, Chytil A, Plieth D, Gorska AE, Dumont N, Shappell S, Washington MK, Neilson EG, Moses HL. TGF-beta signaling in fibroblasts modulates the oncogenic potential of adjacent epithelia. Science. 2004; 303:848-851. [PubMed: 14764882]

19. S ELA, Mager I, Breakefield XO, Wood MJ. Extracellular vesicles: biology and emerging therapeutic opportunities. Nature reviews. Drug discovery. 2013; 12:347-357. [PubMed: 23584393]

20. Josson S, Gururajan M, Sung SY, Hu P, Shao C, Zhau HE, Liu C, Lichterman J, Duan P, Li Q, Rogatko A, Posadas EM, Haga CL, Chung LW. Stromal fibroblast-derived miR-409 promotes epithelial-to-mesenchymal transition and prostate tumorigenesis. Oncogene. 2015; 34:2690-2699. [PubMed: 25065597]

21. Josson S, Gururajan M, Hu P, Shao C, Chu GY, Zhau HE, Liu C, Lao K, Lu CL, Lu YT, Lichterman J, Nandana S, Li Q, Rogatko A, Berel D, Posadas EM, Fazli L, Sareen D, Chung LW. miR-409-3p/-5p promotes tumorigenesis epithelial-to-mesenchymal transition and bone metastasis of human prostate cancer. Clin Cancer Res. 2014; 20:4636-4646. [PubMed: 24963047]

22. Gururajan M, Josson S, Chu GC, Lu CL, Lu YT, Haga CL, Zhau HE, Liu C, Lichterman J, Duan P, Posadas EM, Chung LW. miR-154* and miR-379 in the DLK1-DIO3 microRNA mega-cluster regulate epithelial to mesenchymal transition and bone metastasis of prostate cancer. Clinical cancer research : an official journal of the American Association for Cancer Research. 2014; 20:6559-6569. [PubMed: 25324143]

23. Barron DA, Rowley DR. The reactive stroma microenvironment and prostate cancer progression. Endocrine-related cancer. 2012; 19:R187-R204. [PubMed: 22930558]

24. Wong YN, Ferraldeschi R, Attard G, de Bono J. Evolution of androgen receptor targeted therapy for advanced prostate cancer. Nature reviews. Clinical oncology. 2014; 11:365-376.

25. Hanahan D, Coussens LM. Accessories to the crime: functions of cells recruited to the tumor microenvironment. Cancer Cell. 2012; 21:309-322. [PubMed: 22439926]

26. Chen DS, Mellman I. Oncology meets immunology: the cancer-immunity cycle. Immunity. 2013; 39:1-10. [PubMed: 23890059]

27. Woo SR, Corrales L, Gajewski TF. Innate immune recognition of cancer. Annual review of immunology. 2015; 33:445-474.

28. Schumacher TN, Schreiber RD. Neoantigens in cancer immunotherapy. Science. 2015; 348:69-74. [PubMed: 25838375]

29. Ruffell B, Coussens LM. Macrophages and therapeutic resistance in cancer. Cancer Cell. 2015; 27:462-472. [PubMed: 25858805]

30. Chittezhath M, Dhillon MK, Lim JY, Laoui D, Shalova IN, Teo YL, Chen J, Kamaraj R, Raman L, Lum J, Thamboo TP, Chiong E, Zolezzi F, Yang H, Van Ginderachter JA, Poidinger M, Wong AS, Biswas SK. Molecular profiling reveals a tumor-promoting phenotype of monocytes and macrophages in human cancer progression. Immunity. 2014; 41:815-829. [PubMed: 25453823]

31. Chen W, Konkel JE. Development of thymic Foxp3(+) regulatory T cells: TGF-beta matters. European journal of immunology. 2015; 45:958-965. [PubMed: 25684698]

32. Hussein MR, Al-Assiri M, Musalam AO. Phenotypic characterization of the infiltrating immune cells in normal prostate benign nodular prostatic hyperplasia and prostatic adenocarcinoma. Experimental and molecular pathology. 2009; 86:108-113. [PubMed: 19111537]

33. Gurel B, Lucia MS, Thompson IM Jr, Goodman PJ, Tangen CM, Kristal AR, Parnes HL, Hoque A, Lippman SM, Sutcliffe S, Peskoe SB, Drake CG, Nelson WG, De Marzo AM, Platz EA. Chronic inflammation in benign prostate tissue is associated with high-grade prostate cancer in the placebo arm of the prostate cancer prevention trial Cancer epidemiology biomarkers \& prevention : a publication of the American Association for Cancer Research. cosponsored by the American Society of Preventive Oncology. 2014; 23:847-856.

34. de Visser KE, Eichten A, M L. Coussens, Paradoxical roles of the immune system during cancer development. Nat Rev Cancer. 2006; 6:24-37. [PubMed: 16397525]

35. Crusz SM, Balkwill FR. Inflammation and cancer: advances and new agents. Nature reviews. Clinical oncology. 2015 
36. Pateras IS, Havaki S, Nikitopoulou X, Vougas K, Townsend PA, Panayiotidis MI, Georgakilas AG, Gorgoulis VG. The DNA damage response and immune signaling alliance: Is it good or bad? Nature decides when and where Pharmacology \& therapeutics. 2015; 154:36-56.

37. De Nunzio C, Kramer G, Marberger M, Montironi R, Nelson W, Schroder F, Sciarra A, Tubaro A. The controversial relationship between benign prostatic hyperplasia and prostate cancer: the role of inflammation. European urology. 2011; 60:106-117. [PubMed: 21497433]

38. Shimura S, Yang G, Ebara S, Wheeler TM, Frolov A, Thompson TC. Reduced infiltration of tumor-associated macrophages in human prostate cancer: association with cancer progression. Cancer Res. 2000; 60:5857-5861. [PubMed: 11059783]

39. Nonomura N, Takayama H, Nakayama M, Nakai Y, Kawashima A, Mukai M, Nagahara A, Aozasa $\mathrm{K}$, Tsujimura A. Infiltration of tumour-associated macrophages in prostate biopsy specimens is predictive of disease progression after hormonal therapy for prostate cancer. BJU international. 2011; 107:1918-1922. [PubMed: 21044246]

40. Lanciotti M, Masieri L, Raspollini MR, Minervini A, Mari A, Comito G, Giannoni E, Carini M, Chiarugi P, Serni S. The role of M1 and M2 macrophages in prostate cancer in relation to extracapsular tumor extension and biochemical recurrence after radical prostatectomy. BioMed research international. 2014; 2014:486798. [PubMed: 24738060]

41. Fujii T, Shimada K, Asai O, Tanaka N, Fujimoto K, Hirao K, Konishi N. Immunohistochemical analysis of inflammatory cells in benign and precancerous lesions and carcinoma of the prostate Pathobiology : journal of immunopathology. molecular and cellular biology. 2013; 80:119-126.

42. Comito G, Giannoni E, Segura CP, Barcellos-de-Souza P, Raspollini MR, Baroni G, Lanciotti M, Serni S, Chiarugi P. Cancer-associated fibroblasts and M2-polarized macrophages synergize during prostate carcinoma progression. Oncogene. 2014; 33:2423-2431. [PubMed: 23728338]

43. Escamilla J, Schokrpur S, Liu C, Priceman SJ, Moughon D, Jiang Z, Pouliot F, Magyar C, Sung JL, Xu J, Deng G, West BL, Bollag G, Fradet Y, Lacombe L, Jung ME, Huang J, Wu L. CSF1 receptor targeting in prostate cancer reverses macrophage-mediated resistance to androgen blockade therapy. Cancer Res. 2015; 75:950-962. [PubMed: 25736687]

44. Xu J, Escamilla J, Mok S, David J, Priceman S, West B, Bollag G, McBride W, Wu L. CSF1R signaling blockade stanches tumor-infiltrating myeloid cells and improves the efficacy of radiotherapy in prostate cancer. Cancer Res. 2013; 73:2782-2794. [PubMed: 23418320]

45. Mahon KL, Lin HM, Castillo L, Lee BY, Lee-Ng M, Chatfield MD, Chiam K, Breit SN, Brown DA, Molloy MP, Marx GM, Pavlakis N, Boyer MJ, Stockler MR, Daly RJ, Henshall SM, Horvath LG. Cytokine profiling of docetaxel-resistant castration-resistant prostate cancer. British journal of cancer. 2015; 112:1340-1348. [PubMed: 25867259]

46. Liu G, Lu S, Wang X, Page ST, Higano CS, Plymate SR, Greenberg NM, Sun S, Li Z, Wu JD. Perturbation of NK cell peripheral homeostasis accelerates prostate carcinoma metastasis. The Journal of clinical investigation. 2013; 123:4410-4422. [PubMed: 24018560]

47. Gannon PO, Poisson AO, Delvoye N, Lapointe R, Mes-Masson AM, Saad F. Characterization of the intra-prostatic immune cell infiltration in androgen-deprived prostate cancer patients. Journal of immunological methods. 2009; 348:9-17. [PubMed: 19552894]

48. Pasero C, Gravis G, Granjeaud S, Guerin M, Thomassin-Piana J, Rocchi P, Salem N, Walz J, Moretta A, Olive D. Highly effective NK cells are associated with good prognosis in patients with metastatic prostate cancer. Oncotarget. 2015; 6:14360-14373. [PubMed: 25961317]

49. Johansson A, Rudolfsson S, Hammarsten P, Halin S, Pietras K, Jones J, Stattin P, Egevad L, Granfors T, Wikstrom P, Bergh A. Mast cells are novel independent prognostic markers in prostate cancer and represent a target for therapy. The American journal of pathology. 2010; 177:10311041. [PubMed: 20616342]

50. Fleischmann A, Schlomm T, Kollermann J, Sekulic N, Huland H, Mirlacher M, Sauter G, Simon R, Erbersdobler A. Immunological microenvironment in prostate cancer: high mast cell densities are associated with favorable tumor characteristics and good prognosis. The Prostate. 2009; 69:976-981. [PubMed: 19274666]

51. Pittoni P, Tripodo C, Piconese S, Mauri G, Parenza M, Rigoni A, Sangaletti S, Colombo MP. Mast cell targeting hampers prostate adenocarcinoma development but promotes the occurrence of highly malignant neuroendocrine cancers. Cancer Res. 2011; 71:5987-5997. [PubMed: 21896641] 
52. Templeton AJ, Pezaro C, Omlin A, McNamara MG, Leibowitz-Amit R, Vera-Badillo FE, Attard G, de Bono JS, Tannock IF, Amir E. Simple prognostic score for metastatic castration-resistant prostate cancer with incorporation of neutrophil-to-lymphocyte ratio. Cancer. 2014; 120:33463352. [PubMed: 24995769]

53. Nuhn P, Vaghasia AM, Goyal J, Zhou XC, Carducci MA, Eisenberger MA, Antonarakis ES. Association of pretreatment neutrophil-to-lymphocyte ratio (NLR) and overall survival (OS) in patients with metastatic castration-resistant prostate cancer (mCRPC) treated with first-line docetaxel. BJU international. 2014; 114:E11-E17. [PubMed: 24529213]

54. Fang LY, Izumi K, Lai KP, Liang L, Li L, Miyamoto H, Lin WJ, Chang C. Infiltrating macrophages promote prostate tumorigenesis via modulating androgen receptor-mediated CCL4-STAT3 signaling. Cancer Res. 2013; 73:5633-5646. [PubMed: 23878190]

55. Okada K, Kojima M, Naya Y, Kamoi K, Yokoyama K, Takamatsu T, Miki T. Correlation of histological inflammation in needle biopsy specimens with serum prostate-specific antigen levels in men with negative biopsy for prostate cancer. Urology. 2000; 55:892-898. [PubMed: 10840104]

56. Pittoni P, Colombo MP. The dark side of mast cell-targeted therapy in prostate cancer. Cancer Res. 2012; 72:831-835. [PubMed: 22307838]

57. Taverna G, Giusti G, Seveso M, Hurle R, Colombo P, Stifter S, Grizzi F. Mast cells as a potential prognostic marker in prostate cancer. Disease markers. 2013; 35:711-720. [PubMed: 24324287]

58. Frankel TL, Burns W, Riley J, Morgan RA, Davis JL, Hanada K, Quezado M, Rosenberg SA, Royal RE. Identification and characterization of a tumor infiltrating CD56(+)/CD16 (-) NK cell subset with specificity for pancreatic and prostate cancer cell lines. Cancer immunology, immunotherapy : CII. 2010; 59:1757-1769. [PubMed: 20734041]

59. Kwek SS, Lewis J, Zhang L, Weinberg V, Greaney SK, Harzstark AL, Lin AM, Ryan CJ, Small EJ, Fong L. Preexisting Levels of CD4 T Cells Expressing PD-1 Are Related to Overall Survival in Prostate Cancer Patients Treated with Ipilimumab. Cancer Immunol Res. 2015

60. McArdle PA, Canna K, McMillan DC, McNicol AM, Campbell R, Underwood MA. The relationship between T-lymphocyte subset infiltration and survival in patients with prostate cancer. British journal of cancer. 2004; 91:541-543. [PubMed: 15266325]

61. Ness N, Andersen S, Valkov A, Nordby Y, Donnem T, Al-Saad S, Busund LT, Bremnes RM, Richardsen E. Infiltration of CD8+ lymphocytes is an independent prognostic factor of biochemical failure-free survival in prostate cancer. The Prostate. 2014; 74:1452-1461. [PubMed: 25111810]

62. Liu Y, Saeter T, Vlatkovic L, Servoll E, Waaler G, Axcrona U, Giercksky KE, Nesland JM, Suo $\mathrm{ZH}$, Axcrona K. Dendritic and lymphocytic cell infiltration in prostate carcinoma. Histology and histopathology. 2013; 28:1621-1628. [PubMed: 23729368]

63. Davidsson S, Ohlson AL, Andersson SO, Fall K, Meisner A, Fiorentino M, Andren O, Rider JR. CD4 helper T cells CD8 cytotoxic T cells, and FOXP3(+) regulatory Tcells with respect to lethal prostate cancer Modern pathology : an official journal of the United States and Canadian Academy of Pathology. Inc. 2013; 26:448-455.

64. Ebelt K, Babaryka G, Frankenberger B, Stief CG, Eisenmenger W, Kirchner T, Schendel DJ, Noessner E. Prostate cancer lesions are surrounded by FOXP3+ PD-1+ and B7-H1+ lymphocyte clusters. European journal of cancer. 2009; 45:1664-1672. [PubMed: 19318244]

65. Miller AM, Lundberg K, Ozenci V, Banham AH, Hellstrom M, Egevad L, Pisa P. CD4+CD25high $\mathrm{T}$ cells are enriched in the tumor and peripheral blood of prostate cancer patients. Journal of immunology. 2006; 177:7398-7405.

66. Idorn M, Kollgaard T, Kongsted P, Sengelov L, Thor Straten P. Correlation between frequencies of blood monocytic myeloid-derived suppressor cells regulatory $\mathrm{T}$ cells and negative prognostic markers in patients with castration-resistant metastatic prostate cancer Cancer immunology. immunotherapy : CII. 2014; 63:1177-1187.

67. Jochems C, Tucker JA, Tsang KY, Madan RA, Dahut WL, Liewehr DJ, Steinberg SM, Gulley JL, Schlom J. A combination trial of vaccine plus ipilimumab in metastatic castration-resistant prostate cancer patients: immune correlates Cancer immunology. immunotherapy : CII. 2014; 63:407-418. [PubMed: 24514956] 
68. Andreu P, Johansson M, Affara NI, Pucci F, Tan T, Junankar S, Korets L, Lam J, Tawfik D, DeNardo DG, Naldini L, de Visser KE, De Palma M, Coussens LM. FcRgamma activation regulates inflammation-associated squamous carcinogenesis. Cancer Cell. 2010; 17:121-134. [PubMed: 20138013]

69. Affara NI, Ruffell B, Medler TR, Gunderson AJ, Johansson M, Bornstein S, Bergsland E, Steinhoff M, Li Y, Gong Q, Ma Y, Wiesen JF, Wong MH, Kulesz-Martin M, Irving B, Coussens LM. B cells regulate macrophage phenotype and response to chemotherapy in squamous carcinomas. Cancer Cell. 2014; 25:809-821. [PubMed: 24909985]

70. Woo JR, Liss MA, Muldong MT, Palazzi K, Strasner A, Ammirante M, Varki N, Shabaik A, Howell S, Kane CJ, Karin M, Jamieson CA. Tumor infiltrating B-cells are increased in prostate cancer tissue. Journal of translational medicine. 2014; 12:30. [PubMed: 24475900]

71. Strasner A, Karin M. Immune Infiltration and Prostate Cancer. Frontiers in oncology. 2015; 5:128. [PubMed: 26217583]

72. Ammirante M, Kuraishy AI, Shalapour S, Strasner A, Ramirez-Sanchez C, Zhang W, Shabaik A, Karin M. An IKKalpha-E2F1-BMI1 cascade activated by infiltrating B cells controls prostate regeneration and tumor recurrence. Genes \& development. 2013; 27:1435-1440. [PubMed: 23796898]

73. Shalapour S, Font-Burgada J, Di Caro G, Zhong Z, Sanchez-Lopez E, Dhar D, Willimsky G, Ammirante M, Strasner A, Hansel DE, Jamieson C, Kane CJ, Klatte T, Birner P, Kenner L, Karin M. Immunosuppressive plasma cells impede T-cell-dependent immunogenic chemotherapy. Nature. 2015; 521:94-98. [PubMed: 25924065]

74. Pantel K, Speicher MR. The biology of circulating tumor cells. Oncogene. 2015

75. De Craene B, Berx G. Regulatory networks defining EMT during cancer initiation and progression. Nat Rev Cancer. 2013; 13:97-110. [PubMed: 23344542]

76. Miyamoto DT, Sequist LV, Lee RJ. Circulating tumour cells-monitoring treatment response in prostate cancer. Nature reviews. Clinical oncology. 2014; 11:401-412.

77. Chu GC, Chung LW. RANK-mediated signaling network and cancer metastasis. Cancer Metastasis Rev. 2014; 33:497-509. [PubMed: 24398859]

78. Chu GC, Zhau HE, Wang R, Rogatko A, Feng X, Zayzafoon M, Liu Y, Farach-Carson MC, You S, Kim J, Freeman MR, Chung LW. RANK- and c-Met-mediated signal network promotes prostate cancer metastatic colonization. Endocrine-related cancer. 2014; 21:311-326. [PubMed: 24478054]

79. Chu GC, Wang R, Zhau HE, Posadas E, Chung LW. Metastasis-initiating cells (MICs) as predictors of lethal progression of human prostate cancer. Prostate Cancer Fundation Research Retreats. 2014

80. Hou JM, Krebs M, Ward T, Sloane R, Priest L, Hughes A, Clack G, Ranson M, Blackhall F, Dive C. Circulating tumor cells as a window on metastasis biology in lung cancer. The American journal of pathology. 2011; 178:989-996. [PubMed: 21356352]

81. Krebs MG, Metcalf RL, Carter L, Brady G, Blackhall FH, Dive C. Molecular analysis of circulating tumour cells-biology and biomarkers. Nature reviews. Clinical oncology. 2014; 11:129-144.

82. Hou JM, Krebs MG, Lancashire L, Sloane R, Backen A, Swain RK, Priest LJ, Greystoke A, Zhou C, Morris K, Ward T, Blackhall FH, Dive C. Clinical significance and molecular characteristics of circulating tumor cells and circulating tumor microemboli in patients with small-cell lung cancer. $\mathrm{J}$ Clin Oncol. 2012; 30:525-532. [PubMed: 22253462]

83. Kim MY, Oskarsson T, Acharyya S, Nguyen DX, Zhang XH, Norton L, Massague J. Tumor selfseeding by circulating cancer cells. Cell. 2009; 139:1315-1326. [PubMed: 20064377]

84. Ziaee S, Chu GC, Huang J, Sieh S, Chung LW. Prostate cancer metastasis: roles of recruitment reprogramming cell signal network and three-dimensional growth characteristics. Translational Andrology and Urology. 2015

85. Chu GC, Wang R, Zhau HE, Posadas E, Chung LW. Metastasis-initiating cells (MICs) of circulating tumor cells (CTCs) as predictors of lethal progression of human prostate cancer. 6th Annual SOCCI Research Day. 2015 
86. Zhau HY, Chang SM, Chen BQ, Wang Y, Zhang H, Kao C, Sang QA, Pathak SJ, Chung LW. Androgen-repressed phenotype in human prostate cancer. Proc Natl Acad Sci U S A. 1996; 93:15152-15157. [PubMed: 8986779]

87. Chung LW, Zhau HE, Wu TT. Development of human prostate cancer models for chemoprevention and experimental therapeutics studies. J Cell Biochem Suppl. 1997; 28-29:174-181.

88. Zhau HE, Odero-Marah V, Lue HW, Nomura T, Wang R, Chu G, Liu ZR, Zhou BP, Huang WC, Chung LW. Epithelial to mesenchymal transition (EMT) in human prostate cancer: lessons learned from ARCaP model. Clin Exp Metastasis. 2008; 25:601-610. [PubMed: 18535913]

89. Christman JK. 5-Azacytidine and 5-aza-2'-deoxycytidine as inhibitors of DNA methylation: mechanistic studies and their implications for cancer therapy. Oncogene. 2002; 21:5483-5495. [PubMed: 12154409]

90. Asangani IA, Dommeti VL, Wang X, Malik R, Cieslik M, Yang R, Escara-Wilke J, WilderRomans K, Dhanireddy S, Engelke C, Iyer MK, Jing X, Wu YM, Cao X, Qin ZS, Wang S, Feng FY, Chinnaiyan AM. Therapeutic targeting of BET bromodomain proteins in castration-resistant prostate cancer. Nature. 2014; 510:278-282. [PubMed: 24759320]

91. Henssen A, Thor T, Odersky A, Heukamp L, El-Hindy N, Beckers A, Speleman F, Althoff K, Schafers S, Schramm A, Sure U, Fleischhack G, Eggert A, Schulte JH. BET bromodomain protein inhibition is a therapeutic option for medulloblastoma. Oncotarget. 2013; 4:2080-2095. [PubMed: 24231268]

92. Puissant A, Frumm SM, Alexe G, Bassil CF, Qi J, Chanthery YH, Nekritz EA, Zeid R, Gustafson WC, Greninger P, Garnett MJ, McDermott U, Benes CH, Kung AL, Weiss WA, Bradner JE, Stegmaier K. Targeting MYCN in neuroblastoma by BET bromodomain inhibition. Cancer Discov. 2013; 3:308-323. [PubMed: 23430699]

93. Delmore JE, Issa GC, Lemieux ME, Rahl PB, Shi J, Jacobs HM, Kastritis E, Gilpatrick T, Paranal RM, Qi J, Chesi M, Schinzel AC, McKeown MR, Heffernan TP, Vakoc CR, Bergsagel PL, Ghobrial IM, Richardson PG, Young RA, Hahn WC, Anderson KC, Kung AL, Bradner JE, Mitsiades CS. BET bromodomain inhibition as a therapeutic strategy to target c-Myc. Cell. 2011; 146:904-917. [PubMed: 21889194]

94. Myatt SS, Lam EW. The emerging roles of forkhead box (Fox) proteins in cancer. Nat Rev Cancer. 2007; 7:847-859. [PubMed: 17943136]

95. Teh MT, Gemenetzidis E, Patel D, Tariq R, Nadir A, Bahta AW, Waseem A, Hutchison IL. FOXM1 induces a global methylation signature that mimics the cancer epigenome in head and neck squamous cell carcinoma. PLoS One. 2012; 7:e34329. [PubMed: 22461910]

96. Hwang S, Mahadevan S, Qadir F, Hutchison IL, Costea DE, Neppelberg E, Liavaag PG, Waseem A, Teh MT. Identification of FOXM1-induced epigenetic markers for head and neck squamous cell carcinomas. Cancer. 2013; 119:4249-4258. [PubMed: 24114764]

97. Gemenetzidis E, Elena-Costea D, Parkinson EK, Waseem A, Wan H, Teh MT. Induction of human epithelial stem/progenitor expansion by FOXM1. Cancer Res. 2010; 70:9515-9526. [PubMed: 21062979]

98. Radhakrishnan SK, Bhat UG, Hughes DE, Wang IC, Costa RH, Gartel AL. Identification of a chemical inhibitor of the oncogenic transcription factor forkhead box M1. Cancer Res. 2006; 66:9731-9735. [PubMed: 17018632]

99. Bang C, Thum T. Exosomes: new players in cell-cell communication. The international journal of biochemistry \& cell biology. 2012; 44:2060-2064. [PubMed: 22903023]

100. Camussi G, Deregibus MC, Bruno S, Cantaluppi V, Biancone L. Exosomes/microvesicles as a mechanism of cell-to-cell communication. Kidney Int. 2010; 78:838-848. [PubMed: 20703216]

101. Cocucci E, Racchetti G, Meldolesi J. Shedding microvesicles: artefacts no more. Trends Cell Biol. 2009; 19:43-51. [PubMed: 19144520]

102. Morello M, Minciacchi VR, de Candia P, Yang J, Posadas E, Kim H, Griffiths D, Bhowmick N, Chung LW, Gandellini P, Freeman MR, Demichelis F, Di Vizio D. Large oncosomes mediate intercellular transfer of functional microRNA. Cell Cycle. 2013; 12:3526-3536. [PubMed: 24091630]

103. Di Vizio D, Kim J, Hager MH, Morello M, Yang W, Lafargue CJ, True LD, Rubin MA, Adam RM, Beroukhim R, Demichelis F, Freeman MR. Oncosome formation in prostate cancer: 
association with a region of frequent chromosomal deletion in metastatic disease. Cancer Res. 2009; 69:5601-5609. [PubMed: 19549916]

104. Hager MH, Morley S, Bielenberg DR, Gao S, Morello M, Holcomb IN, Liu W, Mouneimne G, Demichelis F, Kim J, Solomon KR, Adam RM, Isaacs WB, Higgs HN, Vessella RL, Di Vizio D, Freeman MR. DIAPH3 governs the cellular transition to the amoeboid tumour phenotype. EMBO Mol Med. 2012; 4:743-760. [PubMed: 22593025]

105. Record M, Carayon K, Poirot M, Silvente-Poirot S. Exosomes as new vesicular lipid transporters involved in cell-cell communication and various pathophysiologies. Biochim Biophys Acta. 2014; 1841:108-120. [PubMed: 24140720]

106. Ratajczak J, Wysoczynski M, Hayek F, Janowska-Wieczorek A, Ratajczak MZ. Membranederived microvesicles: important and underappreciated mediators of cell-to-cell communication. Leukemia. 2006; 20:1487-1495. [PubMed: 16791265]

107. Vishnubhatla I, Corteling R, Stevanato L, Hicks C, Sinden J. The development of stem cellderived exosomes as a cell-free regenerative medicine. Journal of Circulating Biomarkers. 2014; 3:1-14.

108. Thery C, Boussac M, Veron P, Ricciardi-Castagnoli P, Raposo G, Garin J, Amigorena S. Proteomic analysis of dendritic cell-derived exosomes: a secreted subcellular compartment distinct from apoptotic vesicles. Journal of immunology. 2001; 166:7309-7318.

109. Janowska-Wieczorek A, Majka M, Kijowski J, Baj-Krzyworzeka M, Reca R, Turner AR, Ratajczak J, Emerson SG, Kowalska MA, Ratajczak MZ. Platelet-derived microparticles bind to hematopoietic stem/progenitor cells and enhance their engraftment. Blood. 2001; 98:3143-3149. [PubMed: 11698303]

110. Baj-Krzyworzeka M, Szatanek R, Weglarczyk K, Baran J, Urbanowicz B, Branski P, Ratajczak MZ, Zembala M. Tumour-derived microvesicles carry several surface determinants mRNA of tumour cells and transfer some of these determinants to monocytes. Cancer immunology, immunotherapy : CII. 2006; 55:808-818. [PubMed: 16283305]

111. Ratajczak J, Miekus K, Kucia M, Zhang J, Reca R, Dvorak P, Ratajczak MZ. Embryonic stem cell-derived microvesicles reprogram hematopoietic progenitors: evidence for horizontal transfer of mRNA and protein delivery. Leukemia. 2006; 20:847-856. [PubMed: 16453000]

112. Valadi H, Ekstrom K, Bossios A, Sjostrand M, Lee JJ, Lotvall JO. Exosome-mediated transfer of mRNAs and microRNAs is a novel mechanism of genetic exchange between cells. Nat Cell Biol. 2007; 9:654-659. [PubMed: 17486113]

113. Kim HS, Choi DY, Yun SJ, Choi SM, Kang JW, Jung JW, Hwang D, Kim KP, Kim DW. Proteomic analysis of microvesicles derived from human mesenchymal stem cells. J Proteome Res. 2012; 11:839-849. [PubMed: 22148876]

114. Melo SA, Sugimoto H, O’Connell JT, Kato N, Villanueva A, Vidal A, Qiu L, Vitkin E, Perelman LT, Melo CA, Lucci A, Ivan C, Calin GA, Kalluri R. Cancer exosomes perform cell-independent microRNA biogenesis and promote tumorigenesis. Cancer Cell. 2014; 26:707-721. [PubMed: 25446899]

115. Camussi G, Deregibus MC, Bruno S, Grange C, Fonsato V, Tetta C. Exosome/microvesiclemediated epigenetic reprogramming of cells. Am J Cancer Res. 2011; 1:98-110. [PubMed: 21969178]

116. Wang W, Lotze MT. Good things come in small packages: exosomes immunity and cancer. Cancer Gene Ther. 2014; 21:139-141. [PubMed: 24781373]

117. Thery C, Ostrowski M, Segura E. Membrane vesicles as conveyors of immune responses. Nat Rev Immunol. 2009; 9:581-593. [PubMed: 19498381]

118. Sprague DL, Elzey BD, Crist SA, Waldschmidt TJ, Jensen RJ, Ratliff TL. Platelet-mediated modulation of adaptive immunity: unique delivery of CD154 signal by platelet-derived membrane vesicles. Blood. 2008; 111:5028-5036. [PubMed: 18198347]

119. Roberson CD, Atay S, Gercel-Taylor C, Taylor DD. Tumor-derived exosomes as mediators of disease and potential diagnostic biomarkers. Cancer Biomark. 2010; 8:281-291. [PubMed: 22045359]

120. Zhang HG, Grizzle WE. Exosomes and cancer: a newly described pathway of immune suppression. Clin Cancer Res. 2011; 17:959-964. [PubMed: 21224375] 


\section{Highlights}

Both innate and adaptive immune cells contribute to prostate cancer progression Non-immune and immune stroma regulate each other and their effect on tumor cells Stromal cells exert their influence via direct cell-to-cell contact, soluble factors and extracellular vesicles 


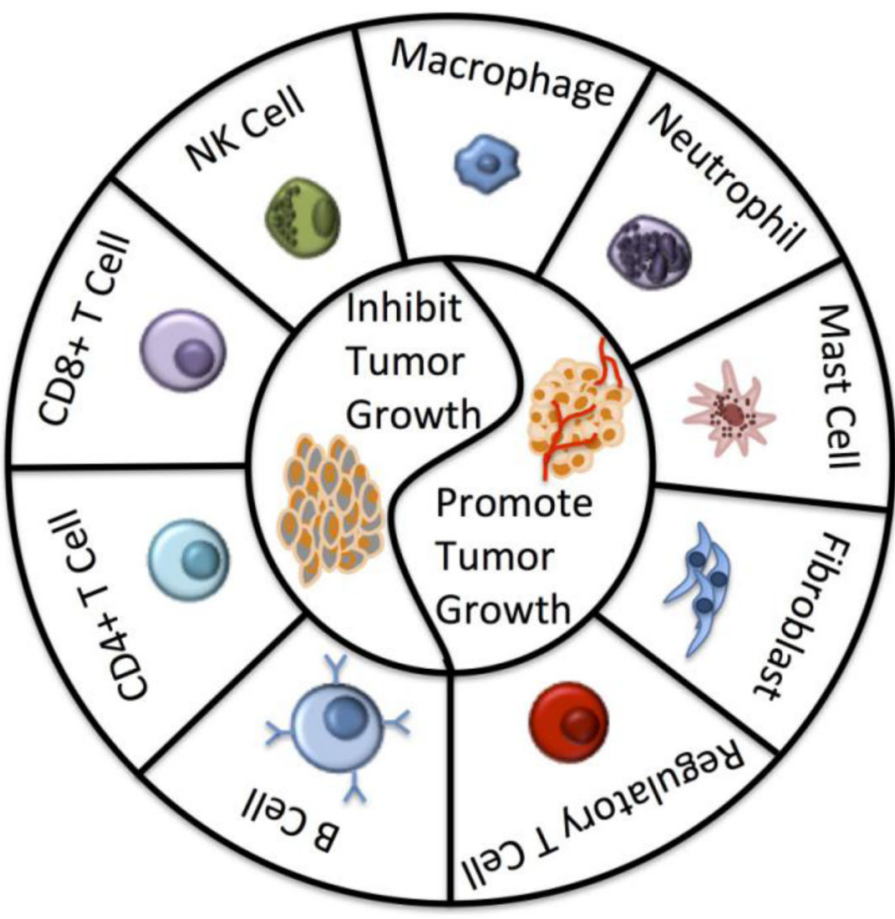

ANTI-TUMORIGENIC

PRO-TUMORIGENIC

\begin{tabular}{|c|c|}
\hline Cell Type & Roles in prostate cancer \\
\hline \multirow[b]{2}{*}{ Mast Cell } & Release cytotoxic cytokines \\
\hline & $\begin{array}{l}\text { Suppress T cell functions } \\
\text { Promote tumor growth and progression }\end{array}$ \\
\hline \multirow{2}{*}{$\begin{array}{l}\text { T cell } \\
\text { (CD8+, } \\
\text { CD4+) }\end{array}$} & $\begin{array}{l}\text { Directly lyse cancer cells } \\
\text { Release cytotoxic cytokines }\end{array}$ \\
\hline & Release tumor promoting cytokines \\
\hline \multirow{2}{*}{$\begin{array}{l}\text { Regulatory T } \\
\text { Cell }\end{array}$} & $\begin{array}{l}\text { Restore homeostasis to reduce chronic } \\
\text { inflammation }\end{array}$ \\
\hline & $\begin{array}{l}\text { Suppress anticancer immune responses } \\
\text { Stimulate inflammatory cytokine production }\end{array}$ \\
\hline \multirow{2}{*}{ Macrophage } & $\begin{array}{l}\text { Release cytotoxic cytokines } \\
\text { Antigen presentation to T cells }\end{array}$ \\
\hline & $\begin{array}{l}\text { Promote angiogenesis, tumor proliferation, } \\
\text { chemotaxis, invasiveness, and metastasis }\end{array}$ \\
\hline \multirow{2}{*}{ Neutrophil } & Direct tumor cell lysis \\
\hline & Recruit immunosuppressive immune cells \\
\hline \multirow[t]{2}{*}{ NK cell } & $\begin{array}{l}\text { Release cytotoxic cytokines } \\
\text { Directly cytotoxic to cancer cells }\end{array}$ \\
\hline & Limited \\
\hline \multirow[b]{2}{*}{ B Cell } & Antibody-mediated lysis of tumor cells \\
\hline & $\begin{array}{l}\text { Release inhibitory cytokines, PD-L1 induction } \\
\text { Production of protumorigenic lymphotoxin }\end{array}$ \\
\hline \multirow[b]{2}{*}{ Fibroblast } & Limited \\
\hline & $\begin{array}{l}\text { ECM remodeling } \\
\text { Release of inhibitory cytokines, growth factors }\end{array}$ \\
\hline
\end{tabular}

Figure 1. Key cell types in the prostate cancer tumor microenvironment

Multiple different cell types shown in Figure 1 have been identified in the prostate cancer stroma and have been found to participate in the development and progression of the disease. Most of the cell types have the potential to either support or promote growth and a summary of their different functions is outlined in the table in Figure 1. 


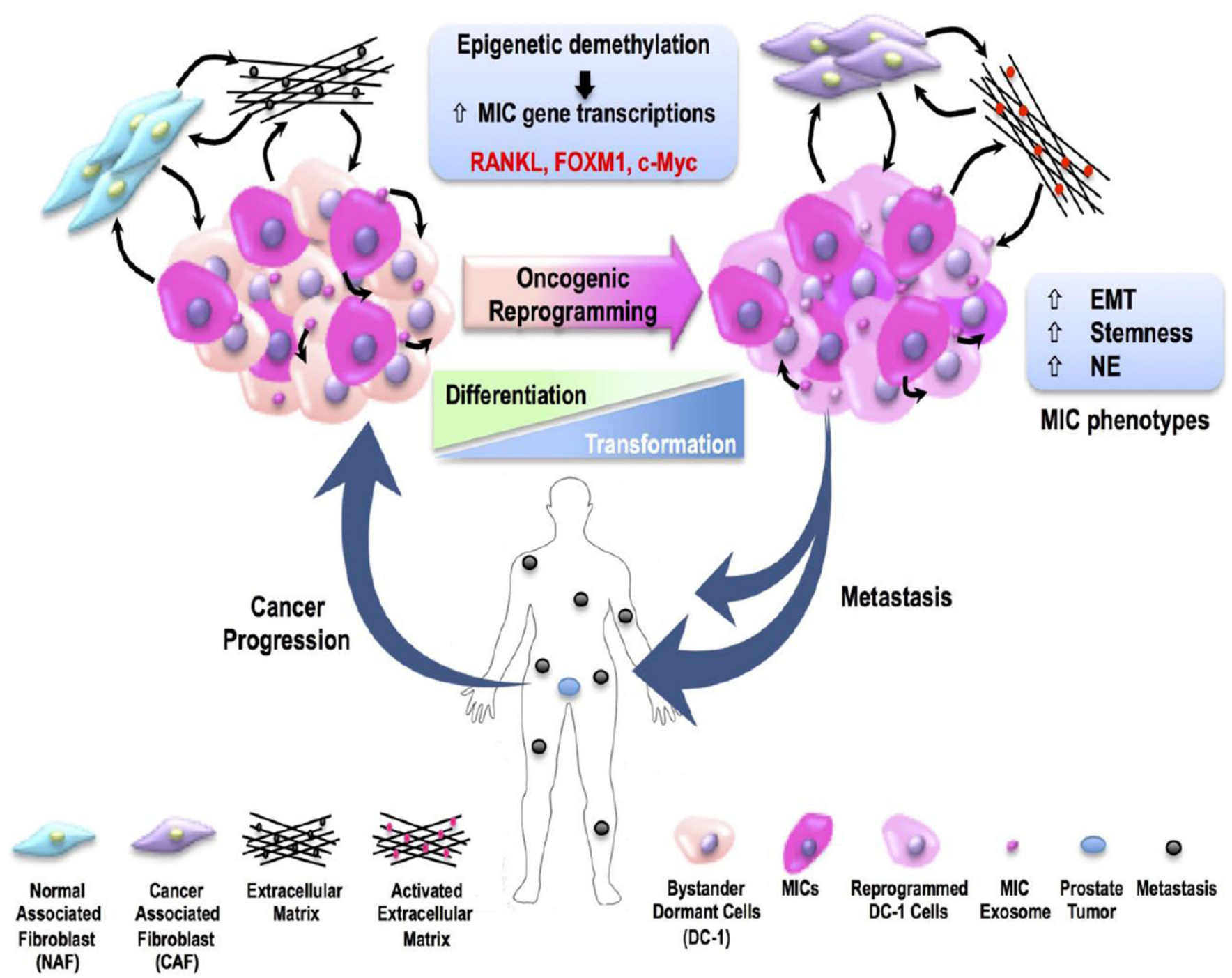

Figure 2. MICs and MIC-secreted exosomes and extracellular matrix alter the tumor microenvironment to promote reprogramming of bystander dormant cells leading to their transformation and de-differentiation

In response to secreted factors from MICs and stromal cells as well as molecules release from the extracellular matrix, bystander dormant cells in prostate cancer can undergo oncogenic reprogramming via epigenetic demethylation of MIC-associated gene promoters. This alteration of bystander cells is mediated by activation of RANKL, FOXM1, and c-Myc to promote prostate cancer cells to undergo EMT and develop enhanced stemness, neuroendocrine and invasive/metastatic phenotypes leading to prostate cancer progression and metastasis. Emerging evidence in the literature suggests that the immune microenvironment surrounding prostate cancer cells can also be modified by extracellular vesicles to either promote or block tumor growth depending upon the nature of the factors transferred. Future studies may reveal novel therapeutic opportunities. 